\title{
Linear programming approach for optimal forest plantation
}

\author{
Zohreh Mohammadi $^{1} \cdot$ Soleiman Mohammadi Limaei $^{1} \cdot$ Taymour Rostami Shahraji $^{1}$
}

Received: 25 November 2014 / Accepted: 26 January 2015 / Published online: 4 October 2016

(C) Northeast Forestry University and Springer-Verlag Berlin Heidelberg 2016

\begin{abstract}
The aim of this research was to identify species suitable for plantation. We first identified species for potentially suitable for plantation based on ecological capabilities regarding soil properties. We determined the area of plantation for different species based on ecological capabilities. Then, we collected relevant data such as growth patterns of different species, labor requirements for plantation and plantation cost. A linear programming model and two integer linear programming models were used for optimization. The appropriate species based on ecological capabilities were ash, elm, maple, oak and bald cypress. A linear programming model was used based on ecological capabilities classification to determine the land area of different species for plantation. Then, two integer linear programming models were employed to select the species for plantation. We set ecological properties unequal for all of the species in the first run of the integer programming model. Two groups were classified: group one included maple and ash; group two included bald cypress, oak and elm. The second integer programming model assumed equal ecological properties for all the species. Results of linear programming showed that maple and bald cypress were appropriate for plantation at the site and their plantation areas should be 151.3 and $355.3 \mathrm{ha}$, respectively. Results of the first integer linear programming model showed that maple and bald cypress would be
\end{abstract}

The online version is available at http://www.springerlink.com.

Corresponding editor: Hu Yanbo.

Soleiman Mohammadi Limaei

limaei@guilan.ac.ir

1 Department of Forestry, Faculty of Natural Resources, University of Guilan, Sowmeh Sara, P.O. BOX 1144, Iran economically profitable for plantation. The results of the second integer linear programming model showed that only bald cypress would be appropriate for plantation.

Keywords Integer linear programming model $\cdot$ Linear programming $\cdot$ Net present value $\cdot$ Plantation

\section{Introduction}

Approximately, half of the global industrial roundwood supply will be provided by plantation and planted forests by the year 2040 (FAO 2013). In addition to producing wood and fiber, forest plantations can provide other ecosystem services such as carbon sequestration, clean water production, regulation of the hydrological cycle, improvement of biodiversity conservation and the alleviation of desertification. It is expected that the relative importance of such services provided by forest plantation will increase in the future (Kanninen 2010). The annual mean rate of forestry has been estimated about 4 million ha. Half of the floristries in the world are for commercial functions, $25 \%$ for non-industrial usage and the other $25 \%$ is not assigned for a particular purpose.

Forest plantations currently make up $5 \%$ of world's forest cover, but account for $35 \%$ of total global industrial wood production. It is estimated that share of forest plantation for wood production will be increased up to $44 \%$ by 2020 (Global outlook for plantations 1999).

About $1 \%$ of the total area of Iran is under forest plantation (FAO 2013). The annual area of coverage of forest plantations is about 63,000 ha. Most forest plantations are implemented with government investment. Tree species planted are generally limited to indigenous or acclimatized exotic species. To ensure maximum success, most forest 
plantations are irrigated during 2-3 seasons. Water shortages are the major constraint for planting, particularly in the arid zones. Site preparation costs are high and development of irrigation facilities is expensive. The state grants substantial support to promote private investment for fast growing tree species plantations such as poplar (Rouchiche and Haji Mirsadeghi 2003). Species such as Populus nigra, Acer velotinum, Fraxinus excelsior, Pinus brutia, Acacia auriculiformis, Eucalyptus camaldulensis, Alnus subcordata, Taxodium distichumin, Alnus glutinosa are the most commonly planted species in Iran (Yousefi et al. 2013).

The ecological aspects of plantations are widely researched in Iran but the economics of forest plantation are usually neglected. The aim of this study was to select appropriate species for forest plantation considering both ecological and economic criteria, and using operations research techniques such as linear programming.

Linear programming (LP) is a powerful tool to formulate and solve practical economic problems and is widely applied in management science. The LP model provides a range of feasible solutions for decision making and this is why we applied LP methods to selection of species for plantation forestry in Iran.

Hof and Baltic (1990) investigated cost effectiveness in the USA national forest system through large-scale optimization. They showed theoretically why allocations of output targets and budgets across national forests should be expected to be inefficient in the absence of large-scale optimization analysis. They also used a multilevel optimization model to develop conservative estimates of the potential for cost savings from large-scale optimization.

Mat Isa (1990) used LP and other mathematical procedures to assess watershed and perpetuity constraints on forest land use for a selected scenario in Terengganu, Peninsular Malaysia. He described the modeling and forecasting estimates of potential timber growth, forest harvest and inventory for use in planning with environmental considerations. Equations were derived for the model to show interaction of sedimentation due to road construction, timber harvesting, and other related forest management activities. Hoganson and McDill (1993) used LP to determine the optimal rotation times for various commercial trees. The LP formulations were compared to examine the impact of forest regulation constraints. The solutions demonstrated that regulation can be expensive, with no simple rules available to describe how a regulated forest can best be achieved or what rotation age should be used for the regulated forest. Phillips et al. (1997) used LP to evaluate potential forest product ventures on former sugarcane lands in Hawaii; a short-rotation forestry decision support system was developed. An application to estimate annual net returns of hypothetical integrated forest product operations established at two former sugarcane plantations was featured. (Tan and Cho 1988) developed a multi-period and multi-objective LP model to capture the complex relationship between factors of production and the constraints operating on these factors of production for a perennial crop plantation. (Rowse and Calum 1998) investigated multiple use forest management planning to examine the economics of joint production for a forested area in Canada. The aim was to maximize net present value (NPV) of timber production and water runoff at three block sizes. Misir and Karahalil (2005) presented an integer linear programming (ILP) model for a five-period harvest problem. Different planning alternatives were developed that maximized timber volume with constraints on the harvesting of adjacent units until regenerated trees reached a certain size. Troncoso et al. (2011) developed an ILP model to evaluate integrating strategies in the forest value chain. They used forest and production information from a Chilean company. The decoupled strategy, where the forest and the industry planning are planned separately, used two models. Their first model dealt with the forest management and harvesting decisions and maximized the expected NPV of logs. They showed that NPV can increase by up to $5 \%$ when an integrated strategy is implemented rather than a decoupled strategy. Moreover, the profit for the business period increased by up to $8.5 \%$. Manley and Threadgill (2013) used a LP forest estate modeling system to model the plantation forests and to estimate future cash flows from them.

\section{Materials and methods}

\section{Study area}

This research was conducted in Shafaroud forest in northern Iran at $36^{\circ} 54^{\prime} \mathrm{N}$ and $45^{\circ} 25^{\prime} \mathrm{E}$ (Fig. 1). Elevation at the study area ranged from 24 to $40 \mathrm{~m}$. The total area of the forest management plan was 1524 ha. About 922.2 ha of the area was planted to forest. The two soils types at this area were: (A) forest brown soil, and (B) pseudogley soil. Forest brown soils were of alluvial origin, moderate in texture, granular to prismatic in structure, and deep. Pseudogley soil was of heavy texture (Table 1) (Shafaroud Forest Management Plan 2008).

The planted species in the study area were poplar (Populus caspica), elm (Alnus glutinosa), loblolly pine (Pinus taeda), hornbeam (Carpinus betulus) and ash (Fraxinus excelsior).

\section{Data collection}

\section{Growth data}

Growth data were collected from previous research in Iranian Caspian forests (Table 2). 


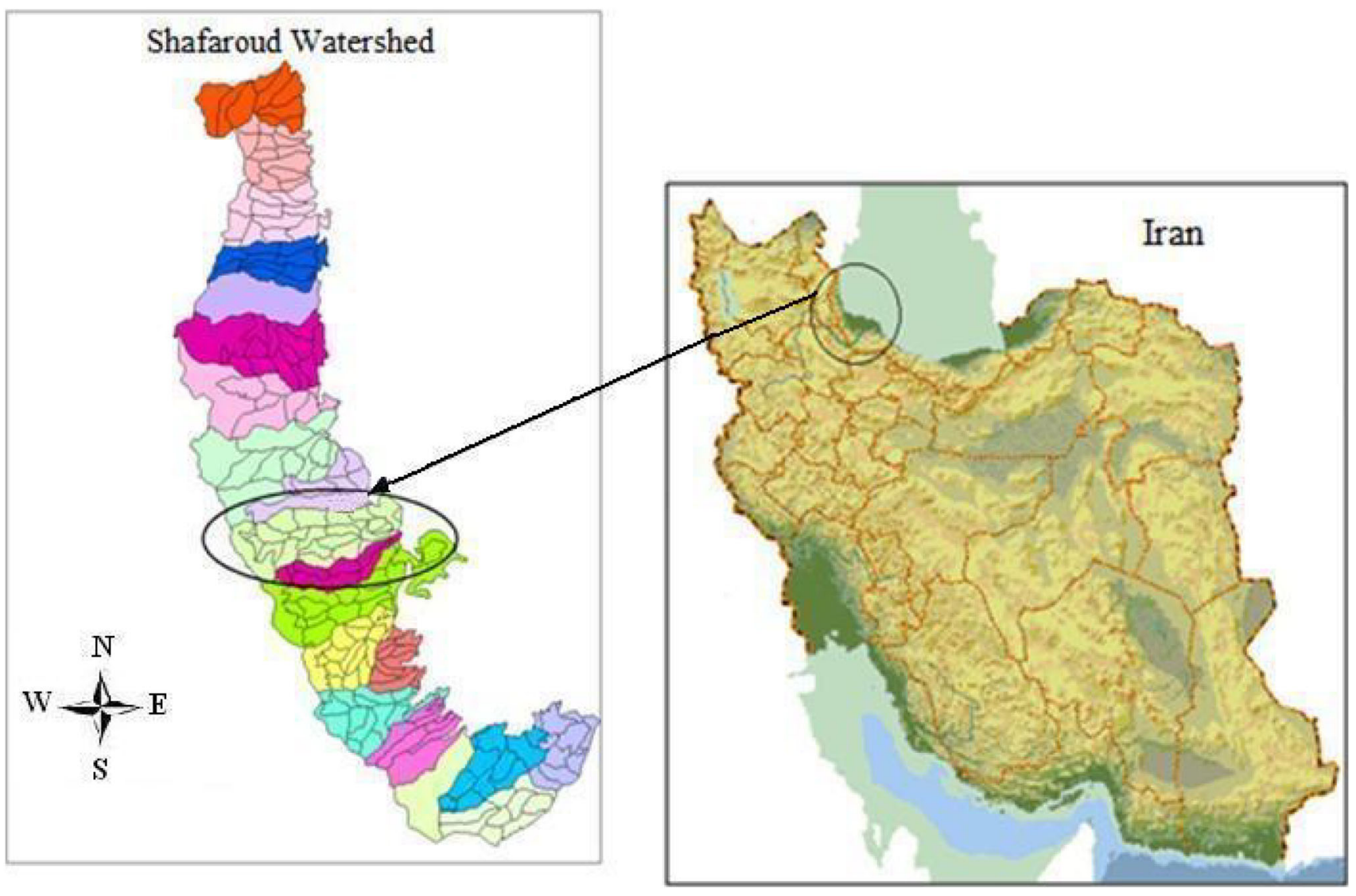

Fig. 1 The study area in Shafaroud watershed management district No. 9

Table 1 Soil type at the forest plantation area

\begin{tabular}{ll}
\hline Land use & Area (ha) \\
\hline Pseudogley soil & 355.58 \\
Forest brown soil & 151.27 \\
Total area under plantation & 922.17 \\
\hline
\end{tabular}

\section{Stumpage price}

Data such as timber price and variable harvesting cost was collected from Shafaroud Forest Company and the General Office of Natural Resources in Guilan province, northern Iran during 1993-2013. The average stumpage price was derived from actual timber, roundwood, fire and pulpwood prices at forest road side minus the variable harvesting costs. Numerical price data were deflated or adjusted using the consumer price index of Iran for the base year of 2011 (Central Bank of the Islamic Republic of Iran 2013) (Table 3).

\section{Labor}

The required amount of labor input for forest plantation and managing was estimated on a per hectare basis at 32 labor per ha (Shafaroud Forest Management Plan 2008).
Table 2 Growth data of different species

\begin{tabular}{lcl}
\hline Species & $\begin{array}{c}\text { Annual average } \\
\text { growth }\left(\mathrm{m}^{3} / \mathrm{ha}\right)\end{array}$ & References \\
\hline Fraxinus excelsior & 6.75 & Ostadhashemi (2013) \\
Acer velutinum & 10.80 & Ostadhashemi (2013) \\
Quercus castanifolia & 8.09 & Ostadhashemi (2013) \\
Alnus glutinosa & 12.90 & $\begin{array}{c}\text { Khanjani Shiraz et al. } \\
(2005)\end{array}$ \\
& & $\begin{array}{c}\text { Mostafanejad and } \\
\text { Taxodium distichumin }\end{array}$ \\
& 8.96 & Sadati (2008) \\
\hline
\end{tabular}

\section{Rotation age}

Rotation age or harvesting time interval was determined using data obtained from Shafaroud Forest Company (Table 4) (Shafaroud Forest Management Plan 2008).

\section{Methods}

\section{Selection of species based on ecological conditions}

Firstly, relevant species (ash, elm, maple, oak, bald cypress) were identified based on ecological conditions. 
Table 3 Real stumpage price of different species during 1993-2013

\begin{tabular}{lllllc}
\hline Year & \multicolumn{4}{l}{ Stumpage price (ten thousands Iranian rials $/ \mathrm{m}^{3}$ ) } \\
\cline { 2 - 6 } & Ash & Maple & Oak & Elm & Bald cypress \\
\hline 1993 & 120.1 & 118.3 & 61.2 & 102.4 & 55.08 \\
1994 & 100.93 & 99.4 & 58.77 & 85.9 & 46.11 \\
1995 & 178.45 & 176 & 134.29 & 154.59 & 92.26 \\
1996 & 221.11 & 218.17 & 156.01 & 192.34 & 116.83 \\
1997 & 246.21 & 242.9 & 143.34 & 214.01 & 129.47 \\
1998 & 260.36 & 256.92 & 195.05 & 226.8 & 138.45 \\
1999 & 290.31 & 286.4 & 191.35 & 252.24 & 152.12 \\
2000 & 347.44 & 342.81 & 260.63 & 302.3 & 183.52 \\
2001 & 317.46 & 313.12 & 223.55 & 275.17 & 164.56 \\
2002 & 274.55 & 270.81 & 183.72 & 238.18 & 142.29 \\
2003 & 283.42 & 279.6 & 191.38 & 246.19 & 146.58 \\
2004 & 266.31 & 262.71 & 180.16 & 231.19 & 137.57 \\
2005 & 245.91 & 242.55 & 168.59 & 213.2 & 126.93 \\
2006 & 258.14 & 230.63 & 165.04 & 196.14 & 124.06 \\
2007 & 229.65 & 212 & 158.24 & 180.41 & 116.43 \\
2008 & 208.37 & 198.28 & 156.9 & 191.56 & 111.04 \\
2009 & 185.42 & 176.31 & 139.62 & 170.25 & 97.54 \\
2010 & 179.58 & 174.72 & 133.05 & 166.62 & 96.55 \\
2011 & 232.75 & 226.09 & 162.28 & 220.32 & 127.42 \\
2012 & 139.57 & 139.57 & 95.96 & 139.57 & 100.85 \\
2013 & 151.55 & 243.01 & 144.93 & 243.01 & 151.55 \\
\hline & & & & & \\
\hline
\end{tabular}

Table 4 Rotation age of different species

\begin{tabular}{ll}
\hline Species & Rotation age (year) \\
\hline Ash & 80 \\
Maple & 80 \\
Oak & 80 \\
Elm & 80 \\
Bald cypress & 40 \\
\hline
\end{tabular}

The species were classified in two groups based on the soil type of the area as below: Group one includes oak, elm and bald cypress and group two includes ash and maple.

\section{Data analysis}

\section{Expected stumpage mean price process}

Regression analysis was used to calculate the stumpage mean price process. The following relation was used for the price estimation:

$P_{t+1}=\alpha+\beta P_{t}+\varepsilon_{t+1}$

$P_{t+1}$ is price at time $\mathrm{t}+1 . P_{t}$ is price at time $t$. We assumed that $\varepsilon$ is a series of normally distributed errors with mean zero and autocorrelation zero, and $0<<1$. Then, the mean of the price process was calculated based on the following equation (Mohammadi Limaei 2006):

$\overline{\mathrm{P}}=\frac{\infty}{1-\beta}$

where $\overline{\mathrm{P}}$ is expected mean price process, $\alpha$ and $\beta$ are estimated parameters from regression analysis.

$N P V$

The NPV of different species for plantation can be calculated by the following function:

$\mathrm{NPV}=\frac{\overline{\mathrm{P}} \times G \times t}{(1+i)^{\mathrm{t}}-1}$

where $G$ is the annual growth $\left(\mathrm{m}^{3} / \mathrm{ha}\right), t$ is rotation age or harvest time interval and $i$ is the real rate of interest in the capital market.

Optimization

LP and two ILP models were used for optimization.

LP model

\section{Objective function}

The aim of the objective function is to maximize the NPV of harvesting according to the following function:

$$
\begin{aligned}
\operatorname{MaxZ}= & 2206.878 \mathrm{X}_{1}+4653.042 \mathrm{X}_{2}+2623.883 \mathrm{X}_{3} \\
& +4319.964 \mathrm{X}_{4}+8064.667 \mathrm{X}_{5}
\end{aligned}
$$

Subject to the following constraints:

$$
\begin{aligned}
& 0.065 \mathrm{X}_{1}+0.065 \mathrm{X}_{2}+0.065 \mathrm{X}_{3}+0.065 \mathrm{X}_{4} \\
& \quad+0.065 \mathrm{X}_{5} \geq 32 \\
& \mathrm{X}_{1}+\mathrm{X}_{2}+\mathrm{X}_{5} \leq 355.58 \\
& \mathrm{X}_{3}+\mathrm{X}_{4} \leq 151.27
\end{aligned}
$$

$$
\begin{aligned}
& 2206.878 X_{1}+4653.042 X_{2}+2623.883 X_{3}+4319.964 X_{4} \\
& \quad+8064.667 X_{5} \geq 2294159.077 \\
& 1200 X_{1}+1200 X_{2}+1200 X_{3}+1200 X_{4} \\
& \quad+1200 X_{5} \leq 608220 \\
& X_{1}, X_{2}, X_{3}, X_{4}, X_{5} \geq 0
\end{aligned}
$$

where $\mathrm{Z}$ is the objective function that should be maximized. $\mathrm{X}_{1}, \mathrm{X}_{2}, \mathrm{X}_{3}, \mathrm{X}_{4}, \mathrm{X}_{5}$ are decision variables (species to be selected for plantation). Whereas, $\mathrm{X}_{1}, \mathrm{X}_{2}, \mathrm{X}_{3}, \mathrm{X}_{4}, \mathrm{X}_{5}$ are oak, elm, ash, maple and bald cypress, respectively. The coefficients of $X_{1}$ to $X_{5}$ in Eq. (4) are the NPV per ha for the above mentioned species (ten thousands Iranian 
Rials/ha). The coefficients of $X_{1}$ to $X_{5}$ in Eq. (5) are the number of required labor for plantation per ha that should be equal or greater than to 32 person. The Eq. (6) is the area constraint for $\mathrm{X}_{1}, \mathrm{X}_{2}, \mathrm{X}_{5}$ that should be equal or less than to 355.58 ha. The Eq. (7) is the area constraint for $\mathrm{X}_{3}, \mathrm{X}_{4}$ that should be equal or less than to 151.27 ha. The coefficient of $X_{1}$ to $X_{5}$ in Eq. (8) are the NPV per ha for the previsions mentioned species that should be equal or greater than to 2294159.077 (ten thousands Iranian Rials). The coefficient of $X_{1}$ to $X_{5}$ in Eq. (9) are the required cost for plantation per ha that should be equal or less than to 608220 (ten thousands Iranian Rials $/ \mathrm{m}^{3}$ ). The Eq. (10) is the non-negative constraint; this ensures that all variables are equal or greater than to zero.

\section{ILP model}

\section{Model 1}

Ecological properties are assumed to be unequal for all species in the first run of the integer programming model. Two groups were classified as group one including maple and ash $\left(X_{3}+X_{4}=1\right)$ and group two including bald cypress, oak and elm $\left(\mathrm{X}_{1}+\mathrm{X}_{2}+\mathrm{X}_{5}=1\right)$.

\section{Objective function}

The aim of the objective function is to maximize the NPV of harvesting according to the following function:

$$
\begin{aligned}
\operatorname{Max}= & 2206.878 \mathrm{X}_{1}+4653.04 \mathrm{X}_{2}+2623.88 \mathrm{X}_{3} \\
& +4319.964 \mathrm{X}_{4}+8064.667 \mathrm{X}_{5}
\end{aligned}
$$

Subject to the following constraints:

$$
\begin{aligned}
& \mathrm{X}_{3}+\mathrm{X}_{4}=1 \\
& \mathrm{X}_{1}+\mathrm{X}_{2}+\mathrm{X}_{5}=1 \\
& \mathrm{X}_{1}, \mathrm{X}_{2}, \mathrm{X}_{3}, \mathrm{X}_{4}, \mathrm{X}_{5} \geq 0
\end{aligned}
$$

where $\mathrm{Z}$ is the objective function that should be maximized. $\mathrm{X}_{1}, \mathrm{X}_{2}, \mathrm{X}_{3}, \mathrm{X}_{4}, \mathrm{X}_{5}$ are the decision variables (species to be selected for plantation).

\section{Model 2}

At this model, ecological properties are assumed to be equal for all species. Hence, there is just one group of species exist for plantation $\left(\mathrm{X}_{1}+\mathrm{X}_{2}+\mathrm{X}_{3}+\mathrm{X}_{4}+\mathrm{X}_{5}=1\right)$. Objective function in Model 2 is:

$$
\begin{aligned}
\operatorname{Max} \mathrm{Z}= & 2206.878 \mathrm{X}_{1}+4653.04 \mathrm{X}_{2}+2623.88 \mathrm{X}_{3} \\
& +4319.964 \mathrm{X}_{4}+8064.667 \mathrm{X}_{5}
\end{aligned}
$$

Subject to the following constraints:
$\mathrm{X}_{1}+\mathrm{X}_{2}+\mathrm{X}_{3}+\mathrm{X}_{4}+\mathrm{X}_{5}=1$

$\mathrm{X}_{1}, \mathrm{X}_{2}, \mathrm{X}_{3}, \mathrm{X}_{4}, \mathrm{X}_{5} \geq 0$

where $\mathrm{Z}$ is the objective function that should be maximized. $\mathrm{X}_{1}, \mathrm{X}_{2}, \mathrm{X}_{3}, \mathrm{X}_{4}, \mathrm{X}_{5}$ are decision variables (species to be selected for plantation).

\section{Results}

\section{Stumpage price process and expected mean price process}

Results of regression analysis showed that there is a significant relation between $P_{t+1}$ and $P_{t}$ at the significant level of 0.05 . The estimated parameters of stumpage price for different species based on Eq. (1) are shown in Table 5. Equation (2) was used in order to determine the expected mean price process based on the estimated parameters in Table 5. The expected mean price process is shown in Table 6.

\section{NPV}

The NPV of different species determined using Eq. (3). Annual average growth $(\mathrm{G})$ was derived from Table 2, rotation age (t) was derived from Table 4 , expected mean price process $(\overline{\mathrm{P}})$ was derived from Table 6 . The real rate of interest in the capital market assumed to be equal to $5 \%$. The results showed that the NPV of ash, elm, maple, oak and bald cypress are 2623.883, 4653.042, 4319.9644, 2206.8788, 8064.667 (ten thousands Iranian Rials), respectively.

\section{Result of LP model}

Results show that the objective value NPV is 3521115 (ten thousands Iranian Rials) for an infinite period. Results of LINGO software are shown in Table 7.

According to the Table 7, the value of decision variables $\left(\mathrm{X}_{4}\right.$ and $\left.\mathrm{X}_{5}\right)$ are 151.2700 and 355.5800 ha, respectively. It means that maple and bald cypress should be planted in areas of 151.2700 and 355.5800 ha, respectively. The other species are not economically profitable for plantation at the study area based on the parameters value of the objective function and the constraints. The results also show that the reduced cost of species $\mathrm{X}_{1}, \mathrm{X}_{2}, \mathrm{X}_{3}$ are $5857.789,3411.625$, and 1696.081 (ten thousands Iranian Rials), respectively. It means that if these values added to the correspondent parameter values on the objective function, these species will be profitable for plantation. 
Table 5 Estimated parameters for stumpage price of different species
Table 6 Expected mean price process of different species

\begin{tabular}{llllll}
\hline Species & $\alpha$ & $\beta$ & \multicolumn{2}{l}{ P value } & \multirow{2}{*}{ Standard deviation $(\varepsilon)$} \\
\cline { 3 - 5 } & & & $\alpha$ & $\beta$ & \\
\hline Ash & 54.745 & 0.768 & 0.01 & 0 & 38.075 \\
Maple & 77.94 & 0.679 & 0.034 & 0 & 40.59 \\
Oak & 65.063 & 0.615 & 0.017 & 0.001 & 31.79 \\
Elm & 82.108 & 0.625 & 0.022 & 0.001 & 37.502 \\
Bald cypress & 42.132 & 0.69 & 0.025 & 0 & 20.151 \\
\hline
\end{tabular}

\begin{tabular}{ll}
\hline Species & Expected mean price process (ten thousands Iranian rials) \\
\hline Ash & 235.96 \\
Maple & 242.803 \\
Oak & 168.994 \\
Elm & 218.95 \\
Bald cypress & 135.909
\end{tabular}

Table 7 Results of LP model solved using LINGO software

\begin{tabular}{lll}
\hline Variable & Value & Reduced cost \\
\hline $\mathrm{X}_{1}$ & 0 & 5857.789 \\
$\mathrm{X}_{2}$ & 0 & 3411.625 \\
$\mathrm{X}_{3}$ & 0 & 1696.081 \\
$\mathrm{X}_{4}$ & 151.27 & 0 \\
$\mathrm{X}_{5}$ & 355.58 & 0 \\
Row & Slack or surplus & Dual price \\
1 & 3521115 & 1 \\
2 & 0.94525 & 0 \\
3 & 0 & 8064.667 \\
4 & 0 & 4319.964 \\
5 & 1226956 & 0 \\
6 & 0 & 0 \\
7 & 0 & 0 \\
8 & 0 & 0 \\
9 & 0 & 0 \\
10 & 151.27 & 0 \\
11 & 355.58 & 0 \\
\hline
\end{tabular}

The amounts of underachieved and overachieved are showed by slack and surplus, respectively (Table 7). Surpluses for the second constraint Eq. (2) at LP model is 0.94 (row 2 in Table 7). It means that the amount of labor is 0.94 person greater than the minimum acceptable level (32 person). Furthermore, the surplus of NPV constraint (row 5 in Table 7) is 1226956. This shows that the amount of NPV is 1226956 million Rials greater than the minimum acceptable level (2294159.077 million Rials). There is not any slack or surplus for the other constraints and it means that their amounts exactly meet.
Dual price shows the value of the resources in the constraint. Therefore, the constraint related to the areas of plantation for species $X_{1}, X_{2}, X_{3}$ (row 3 in Table 7) has the highest dual price (8064.667). Therefore, if the forest manager be able to increase the areas of these three species (oak, elm and bald cypress), he/she can get higher NPV. The second important resource is the area of plantation for species $\mathrm{X}_{3}, \mathrm{X}_{4}$ according to its dual price value (4319.964) (row 4 in Table 7). The shadow prices of the other constraints are zero and one unit changes of this constraint do not affect the NPV.

\section{Result of ILP model}

\section{ILP model 1}

Results of LINGO software are shown in Table 8. Results show that the objective value (NPV) is 12384.63 (ten thousands Iranian Rials) for an infinite period. Results also show that variables such as $X_{4}$ and $X_{5}$ have value 1 . Therefore, maple and bald cypress are selected for planation. The reduced cost for decision variables $\mathrm{X}_{1}, \mathrm{X}_{2}, \mathrm{X}_{3}$ are 5857.789, 3411.625 and 1696.081 (ten thousands Iranian Rials), respectively. Hence, if these values added to the correspondent parameter values on the objective function, these species will be profitable for plantation. The shadow price of ILP Model 1 is same as LP model.

\section{ILP model 2}

Results show that the objective value NPV is 8064.667 (ten thousands Iranian Rials) for an infinite period. Results of LINGO software for ILP Model 2 are shown in Table 9. 
Table 8 Results of ILP Model 1, solved using LINGO software

\begin{tabular}{lll}
\hline Variable & Value & Reduced cost \\
\hline$X_{1}$ & 0 & 5857.789 \\
$X_{2}$ & 0 & 3411.625 \\
$X_{3}$ & 0 & 1696.081 \\
$X_{4}$ & 1 & 0 \\
$X_{5}$ & 1 & 0 \\
Row & Slack or surplus & Dual price \\
1 & 12384.63 & 1 \\
2 & 0 & 0 \\
3 & 0 & 0 \\
4 & 0 & 0 \\
5 & 1 & 0 \\
6 & 1 & 0 \\
7 & 0 & 8064.667 \\
8 & 0 & 4319.964 \\
\hline
\end{tabular}

According to the Table 9, results of the second model of ILP showed that if we assume the same ecological conditions for different species, the bald cypress will be selected for plantation.

\section{Discussion}

The aim of this research was to apply LP and ILP models to determine the appropriate species for forest plantation in Shafaroud Forest Company, north of Iran. The results indicated that species such as maple and bald cypress are more profitable for plantation at the study area. Results of LP model showed that bald cypress and maple are suitable for plantation at the area and have the highest shadow prices. This means that if the forest managers be able to increase the plantation area of these two species, they will gain higher NPV. Results of the ILP Model 1 showed that maple and bald cypress are selected for plantation as they have the highest NPV. Results of ILP Model 2 show that bald cypress will be selected for plantation.

LP offers considerable promise as an aid to decision making for difficult natural resource management problems; with the wide availability of inexpensive microcomputers, problems of moderate size and difficulty can be solved and used to provide information useful to decision makers. Analysts must recognize, however, that decision makers often consider many factors in addition to those that might easily be specified in a LP model (Kowero and Dykstra 1988).

The management planning of forest plantation is a complex activity. It is possible to get an optimal solution using LP in forest plantation. The LP model is helpful in illustrating the economic inter relationships among rotation
Table 9 Results of ILP Model 2, solved using LINGO software

\begin{tabular}{lll}
\hline Variable & Value & Reduced cost \\
\hline $\mathrm{X}_{1}$ & 0 & 5857.789 \\
$\mathrm{X}_{2}$ & 0 & 3411.625 \\
$\mathrm{X}_{3}$ & 0 & 5440.787 \\
$\mathrm{X}_{4}$ & 0 & 3744.703 \\
$\mathrm{X}_{5}$ & 1 & 0 \\
Row & Slack or surplus & Dual price \\
1 & 12384.63 & 1 \\
2 & 0 & 0 \\
3 & 0 & 0 \\
4 & 0 & 0 \\
5 & 1 & 0 \\
6 & 1 & 0 \\
7 & 0 & 0 \\
8 & 0 & 8064.667 \\
\hline
\end{tabular}

length, adopted period for conversion to sustained yield and NPV of the forest (Duangsathaporn and Prasomsin 2005). Kowero and Dykstra (1988) developed a timestaged LP model of the cypress, pine, and eucalyptus plantations in Tanzania. The aim was to maximize the NPV of timber produced from the forest during the planning horizon. The results indicated that the estimated first-period budget of Shs 12 million is required because the solution specifies afforestation of 502.5 ha of cypress. Costs to the forest project during the first 5 years would therefore increase by an average of Shs 140000 annually. Their results showed that cypress species have to plant in more area. The results of their study were somehow similar to the results of this study for selecting suitable species in forest plantation.

(Tan and Cho 1988) used LP method to determine the profit maximizing alternative or combination of alternative among the four cropping systems in Malaysia. Their result show that both labor and land constraints are binding most of these optimal plans. Thus, the results do reflect the relatively higher labor cost in rubber production.

Mgeni and Price (1993) planned forest plantation investments with the aid of LP in Tanzania. The objective function is maximization of land expectation value under financial, economic or social pricing and using the appropriate discount rates. Constraints were seedling, budget and labor. Results indicated that demand for unskilled labor per ha differs considerably among various land preparation types. Phillips et al. (1997) estimated annual net returns of hypothetical integrated forest product operations established at two former sugarcane plantations is featured. From a variety of Eucalyptus saligna plantation management and wood processing options, LP results indicate that the optimal profit opportunity exists for the production of 
medium density fiberboard and plywood from E. saligna plantations. Duangsathaporn and Prasomsin (2005) investigated the advantage of a LP model in forestry. The model permits specification of the management program in an irregular trend that will maximize the NPV of expected yields while converting the irregular forest to regulated plantations in a finite period. At the end of the planning horizon, the forest plantation age/size class distribution would be such that the forest could produce approximately equal annual or periodic harvests of timber.

Vanlisuta and Prombanpong (2012) determined the number and species of trees to be planted in order to maximize a profit through an ILP model. The mathematical model is developed in terms of the profit function. This objective function is therefore, a difference between carbon credit revenue and costs of plantation. The economical plants are only considered in the model. Consequently, fourteen different tree species are to be investigated. The objective function is subjected to several constraints i.e. planting area, carbon sequestration and so on. It is found that three kinds of plants, Copper pod, Cananga, and Bullet wood are suitable for planting.

Cruz-Bello and Sotelo-Ruiz (2013) presented a geospatial decision making tool to identify suitable areas for restoration. The overall approach entails (1) the use of the simple multi attribute rating technique to identify and rank the attributes according to their importance for prioritizing areas for restoration and (2) the implementation of 0-1 integer programming to select the areas that maximize the environmental benefit. Specialists in different aspects of reforestation selected the following attributes to identify priority areas for reforestation: erosion, land use/land cover, position in the watershed, soil type, terrain slope, and precipitation. In total, 644,642 ha were classified under very high priority for reforestation. Of these, 17,059 ha were selected to maximize the environmental benefit without exceeding the available budget.

Manley and Threadgill (2013) used LP model for valuation and planning of New Zealand plantation forests. The system was used to help set reserve prices and provide indicative valuations. They showed that higher log prices and less constrained management strategy will increases forest value, assumption of higher harvesting costs will decrease forest value. Wang et al. (2014) examined practically possible ranges of mean annual increment, general inflation rate, rate of forest fund, and interest rate in northeastern China. They computed NPV, equivalent annual income (EAI) and internal rate of return (IRR). Results showed NPV ranged from $\$ 1,024$ to $\$ 6,925$ per ha, EAI ranged from $\$ 120$ to $\$ 623$ ha per year, and IRR ranged from 13.2 to $29.3 \%$. They show that growing poplar plantations could be two times more profitable than managing the existing natural forests in the study area by referring to EAI values.

\section{Conclusion and recommendation}

Bald cypress as a softwoods species is the first priority for forest plantation at the study area according to the results of LP. This species is a fast growing tree, therefore it has short rotation period. Due to the expansion of wet lands in the coastal and flat areas at north of Iran as well as the industrial importance of this species such as producing suitable pole and tunnel wood, it is suggested to plant this species on a large scale at this area. Demand of wood is higher than its supply in Iran. Hence, the plantation of the fast growing species can reduce the shortage of domestic wood in Iran. Maple as a softwoods species is the second priority for plantation according to the results of LP. Maple is a native species in northern forests. This species, can produce high volume of wood, it can reduce the fertility problems in forest. Also it can answer to soil acidification by planting non-native confers (Kiyan and Jalilvand 2011). The plantation in Iran usually carried out by Forests, Rangeland and Watershed Management Organization of Iran without considering simultaneously economic and ecological criteria. Here we considered both criteria to determine the appropriate species. Therefore, the results of this study can be a guide for the forest manager to consider economic and ecological criteria in forest plantation.

\section{References}

Central Bank of the Islamic Republic of Iran (2013) Consumer price index report. www.cbi.ir

Cruz-Bello GM, Sotelo-Ruiz ED (2013) Coupling spatial multiattribute analysis and optimization to identify reforestation priority areas: a case Study in Central Mexico. Mt Res Dev 33(1):29-39

Duangsathaporn K, Prasomsin P (2005) Application of linear programming in forestry: management planning for a forest plantation. In: Operation Research Conference, Graduate School of Applied Statistics, Bangkok, Thailand, September 2005

FAO (2013) Global data on forest plantations resources. http://www. fao.org/docrep/004/Y2316E/y2316e0b.htm

Global outlook for plantations (1999) ABARE research report (Australia), no. 99.9/Australian Bureau of Agricultural and Resource Economics, Canberra, p 99

Hof JG, Baltic TJ (1990) Cost effectiveness from regional optimization in the USDA Forest service. J For Sci 36(16):939-954

Hoganson HM, McDill ME (1993) More on forest regulation: an LP perspective. Soc Am For 39(27):321-347

Kanninen M (2010) Plantation forests global perspective. In: Bauhus J, van der meer PJ, kanninen M (Eds). Ecosystem goods and services from plantation forests, pp. 1-15

Khanjani Shiraz B, Adeli A, GorjiBahri Y (2005) The investigation and comparative of growth and wood production of Alnus glutinosa, west of Guilan province (North of Iran). Pajouheshva-Sazandegi J 69:14-25 (In Persian)

Kiyan G, Jalilvand H (2011) Measurement of diameter increment and standing volume of maple (Acer velutinum) plantations (case study: Talu Kola and Emre 2district, compartment No. 1). For Rang Mag 90-91:22-28 (In Persian) 
Kowero GS, Dykstra DP (1988) Improving long-term management plans for a forest plantation in Tanzania, using LP. For Ecol Manag 24:203-217

Manley BR, Threadgill JA (2013) LP Used for valuation and planning of New Zealand plantation forests. Oper Res Manag Sci 21(6):66-79

Mat Isa AZ (1990) The application of LP for forest land use and timber management planning with watershed considerations in Terengganu, Peninsular Malaysia. Oregon State University, Corvallis, p 107

Mgeni ASM, Price C (1993) Planning of forest plantation investments with the aid of LP: a case study of Sao Hill Forest, Tanzania. For Ecol Manag 62:51-72

Misir M, Karahalil U (2005) Overcoming spatial constraints in forest management using integer programming: a case study. In: The 7th Balkan Conference on operational research. BACOR 05. Constanta, May 2005, Romania

Mohammadi Limaei S (2006) Economically optimal values and decisions in Iranian forest management. Swedish university of agricultural sciences (SLU), Umea, p 110

Mostafanejad SR, Sadati SE (2008) Results of adaptation trial with three Taxodiaceae species at Chamestanplain Mazandaran province. For Pop Res 16(2):230-240

Ostadhashemi R, RostamiShahraji T, Roehle H, Mohammadi Limaei S (2013) Carbon production potential of different tree species plantations in north of Iran. Ann Biol Res 4(12):106-114

Phillips VD, Tvedten AE, Liu W, Merriam RA (1997) Integrated forest products from former sugarcane plantations in Hawaii. For Ecol Manag 92:29-38
Plan Shafaroud Forest Management (2008) Forest plantation schedule in Gisom-Pilambara area, Iranian Forests. Rangelands and watershed management organization, Tehran, p 298

Rouchiche S, Haji Mirsadeghi MA (2003) Role of planted forests and trees outside forests in sustainable forest management: Islamic Republic of Iran-Country case study. Working paper FP/32E, FAO, Rome, Oct 2003

Rowse J, Calum JC (1998) Forest harvesting to optimize timber production and water runoff. Soc-Econ Plan Sci 32(4):277-293

Tan LP, CO Fong (1988) Determination of the crop mix of a rubber and oil plam plantation-a programming approach. Eur J Oper Res 34:362-371

Troncoso J, D'Amours S, Flisberg P, Roennqvist M, Weintraub A (2011) A mixed integer programming model to evaluate integrating strategies in the forest value chain-a case study in the Chilean forest industry, University of Montreal, Canada, working paper, CIRRELT-2011-28, p 29

Vanlisuta C, Prombanpong S (2012) An integer programming approach to optimize the plantation in order to reduce global warming. Adv Mater Res 548:767-771

Wang YY, Bai GX, Shao GF, Cao Y (2014) An analysis of potential investment returns and their determinants of poplar plantations in state-owned forest enterprises of China. New For 45:251-264

Yousefi M, Pourmajidian MR, Karimi M, Darvishi L (2013) Quantitative and qualitative evaluation of forest plantations by four species and suggestion the appropriate species in the Hyrcanian forest. Eur J Exp Biol 3(5):352-360 